\title{
Influência do lexema 'coronavírus' no léxico polaco e português
}

\section{The Influence of the Lexeme 'coronavirus' in the Polish and Portuguese Lexicon}

\author{
EDYTA JABŁonKA [edyta.jablonka@poczta.umcs.lublin.pl]
}

Uniwersytet Marii Curie-Skłodowskiej w Lublinie, Polónia

\begin{abstract}
RESUMO
A pandemia da COVID-19 tem provacado o surgimento de várias modificações em todas as áreas de atividades humanas, então, não é de estranhar que tenha provocado também muitas alterações importantes no léxico. Devido ao aparecimento de novos fenómenos são criados vários neologismos relacionados com o novo coronavírus. No presente estudo, gostávamos de concentrar-nos na apresentação das palavras com o componente 'corona', proveniente do coronavírus cujo surgimento tem marcado a nossa realidade a partir de março de 2020. Decidimos comparar duas línguas pertencentes a dois sistemas diferentes - o português e o polaco, portanto, a nossa pesquisa permite observar que existem algumas proximidades entre as línguas em questão. Vale a pena sublinhar que o léxico relacionado com a pandemia é muito rico e alguns lexemas já são verificáveis nos dicionários enquanto outros ainda estão a ser introduzidos no léxico, ou são frequentes na Internet, mas o seu futuro é difícil de determinar.
\end{abstract}

\section{Palavras-chave}

Neologia; neologismo; coronavírus; português; polaco; COVID-19

\begin{abstract}
The COVID-19 pandemic has provoked the appearance of several numerous in all areas of human activities, so it is not surprising that it has also caused many important changes in the lexicon of each language. Due to the appearance of new phenomena, several neologisms related to the new coronavirus and the disease caused by it are created. In our study, we would like to focus on word formation processes with the 'corona' component, from the 'new coronavirus' whose emergence has marked our reality since 2020 . We decided to compare two languages belonging to two different systems - Portuguese and Polish, therefore, our research shows that there are many similarities between the languages in question. It is worth underlining that the lexicon related to the pandemic is very rich and many of the terms are already verifiable in the dictionaries while others are still being introduced in the lexicon and their future is difficult to determine.
\end{abstract}

\section{KEYWORDS}

Neology; neologism; coronavirus; Portuguese; Polish; COVID-19

RECEBIDO 2021-04-30; ACEITE 2021-05-20 


\section{Introdução}

Com o acesso a novas tecnologias, a comunicação entre as pessoas torna-se mais fácil e várias novas palavras propagam-se na sociedade de maneira muito dinâmica. Nos últimos anos, o surgimento de novas palavras e expressões tem sido mais frequente na imprensa, na televisão e no mundo virtual. Por necessidade ou por moda, a entrada constante de várias unidades lexicais é inevitável. A variabilidade e a dinamicidade da língua são visíveis no léxico sendo úteis para as comunidades falantes. No entanto, perante o dinamismo do léxico, a tarefa de normalizá-lo torna-se difícil e pouco transparente, o que é possível observar também desde o surgimento do novo coronavírus e da doença por ele provocada. Este acontecimento tem tido uma forte influência em todos os domínios de atividades humanas e tem provocado o aparecimento de diferentes neologismos relacionados com a pandemia. O nosso objetivo é o de apresentar um estudo sobre esta temática concentrado no português e no polaco, baseado no corpus reunido dos dicionários e das páginas web. A estrutura planeada do artigo assenta-se no enquadramento teórico relacionado com o papel da neologia nos estudos linguísticos ao qual se segue a apresentação dos dados recolhidos principalmente das fontes eletrónicas portuguesas e polacas, apoiada também na pesquisa lexicográfica realizada em dicionários disponíveis na versão eletrónica.

O nosso estudo parece ser justificado não só por inventariar e definir as palavras, mas também por discutir algumas questões relacionadas com a dicionarização de novas unidades lexicais em Portugal e na Polónia, assim como demonstrar as diferenças e as proximidades entre os dois países. As palavras que tomamos em consideração ainda não são registadas em todos os dicionários que consultámos, contudo, algumas já se encontram em dicionários eletrónicos ou glossários disponíveis online. Trata-se das alterações muito dinâmicas nos sistemas lexicais do português e do polaco que têm acontecido devido à pandemia. Desde o seu início têm surgido muitos neologismos entre os quais distinguimos palavras compostas, contaminações ${ }^{1}$, híbridos ${ }^{2}$, amálgamas ${ }^{3}$ ou empréstimos. As duas línguas foram influenciadas pelo aparecimento de termos especializados, sobretudo relacionados com a medicina, mas também verificamos muitos neologismos resultantes da nova realidade. Os exemplos reunidos permitem estudar os padrões reais de uso de língua em textos naturais, convém salientar também que o corpus é atual, reunido à base dos textos escritos durante a pandemia. Por isso, escolhemos a definição de Sánchez (1995) como mais adequada para o nosso estudo e consideramos o nosso corpus como "conjunto de dados linguísticos (pertencentes ao uso oral ou escrito da linguagem, ou ambos), sistematizado segundo determinados critérios [...] de maneira que sejam representativos da totalidade do uso linguístico ou de algum dos seus âmbitos." (Sánchez 1995: 8-9)

1 Influência por analogia entre duas unidades linguísticas.

2 Híbridos são as palavras compostas por elementos provenientes de línguas diferentes.

3 Como amálgamas, percebemos novas palavras que resultam do cruzamento de duas ou mais, reunindo numa única alguns segmentos dessas palavras originárias. 


\section{Enquadramento teórico}

\subsection{Definição e função do léxico}

O léxico constitui o conjunto das palavras duma língua, enquanto o vocabulário é o conjunto dos vocábulos que existem na língua realmente num determinado lugar e num determinado tempo (Vilela 1995: 13). Para completar esta definição, acrescentemos ainda as seguintes considerações:

O léxico é entendido como o conjunto de todas as palavras de uma língua, também chamadas de lexias. As lexias são unidades de características complexas cuja organização enunciativa é interdependente, ou seja, a sua textualização no tempo e no espaço obedece a certas combinações. Embora possa parecer um conjunto finito, o léxico de cada uma das línguas é tão rico e dinâmico que mesmo o melhor dos linguistas não seria capaz de enumerá-lo. Isto ocorre porque dele faz parte a totalidade das palavras, desde as preposições, conjunções ou interjeições, até os neologismos, regionalismos ou terminologias, passando pelas gírias, expressões idiomáticas, provérbios ou palavrões. ${ }^{4}$

O léxico é de natureza pluridimensional, que constitui um componente importante da língua cuja função é "produzir, armazenar, processar e transmitir signos que os falantes usam como matéria-prima na elaboração de raciocínios e na construção de enunciados verbais" (Rio-Torto 2006: 2). O léxico é considerado um sistema aberto, em transformação, tratado como um conjunto de todas as palavras de que dispõem os falantes de uma determinada língua num determinado tempo e espaço. O número de palavras pode variar por diferentes razões. As palavras são relacionadas entre si pelas regras gramaticais, servem para construir textos, componente básico do ato de comunicação verbal. Segundo Vilela, o léxico é "a codificação da realidade extralinguística interiorizada no saber de uma dada comunidade linguística. Ou, numa perspectiva comunicativa, é o conjunto das palavras por meio das quais os membros de uma comunidade linguística comunicam entre si" (Vilela 1995: 13). Pode-se, então, definir o léxico também como a "totalidade das palavras duma língua, ou, como o saber interiorizado, por parte dos falantes de uma comunidade linguística, acerca das propriedades lexicais das palavras (propriedades fonético-fonológico-gráficas, propriedades sintácticas e semânticas)" (Vilela 1994: 10).

O léxico de uma língua constitui um conjunto de experiências adquiridas pelos seus falantes. Este conjunto formou-se de unidades, criadas pelas necessidades e interações de diferentes grupos sociais, formando assim o universo lexical:

Usando o léxico, as comunidades falantes realizam uma espécie de reciclagem do material lexical disponível, quer dizer, formam as palavras novas aproveitando vários métodos para construí-las: "[...] ganha sentido afirmar que o léxico é mais do que uma lista de palavras à disposição dos falantes. É mais do que um repertório de unidades. É um depositário de recortes com que cada comunidade vê o mundo, as coisas que a cercam, o sentido de tudo" (Antunes 2007: 42).

4 http://www.letras.ufmg.br/padrao_cms/?web=gtlex\&lang=1\&page=2329\&menu=1547\&tipo=1 (consultado em 10-04-2021). 
O léxico "inclui a nomenclatura de todos os conceitos linguísticos e não linguísticos e de todos os referentes do mundo físico e do universo cultural, criado por todas as culturas humanas atuais e do passado" (Biderman 1981: 138). O léxico também "desempenha um papel essencial na comunicação de qualquer sujeito falante, tanto na sua função de receptor, como na sua posição de emissor, sendo a última ratio a construção do seu conhecimento" (Teixeira 2010: 21).

\subsection{Neologia e neologismos}

A mudança linguística no léxico consiste normalmente em dois processos: o processo de queda em desuso e a passagem ao estatuto do arcaísmo, assim como o processo de aparecimento de novas palavras - os neologismos. Boulanger (1989: 202) define a neologia como processo de criação de unidades lexicais, gerais ou terminológicas, pelo recurso aos mecanismos de criatividade lexical de que uma língua dispõe. Segundo Guilbert (1975), a neologia ocupa-se dos fenómenos linguísticos de ordem fonética, fonológica, morfológica, sintática, semântica e lexical, que ocorrem em certos momentos numa dada língua. Então, como neologismo, podemos tratar uma palavra que é resultado de um destes processos, uma palavra percebida como nova pelos falantes da língua dada. Como diz Cabré, "o neologismo pode-se definir como uma unidade léxica de formação recente, uma aceção nova de um termo já existente ou um termo emprestado há pouco de um sistema linguístico estrangeiro" (Cabré 1993: 444). Estas novas unidades podem ser aceites pela comunidade falante e perder o estatuto de neologismo, ou não se adaptar e desaparecer do sistema linguístico. $\mathrm{O}$ fator de frequência parece muito importante: quanto mais a palavra é usada, mais facilmente entra no acervo lexical de uma língua, perdendo este valor de novidade, torna-se numa palavra regular entre os falantes. A fase de dicionarização normalmente marca o fim do processo da adaptação dos neologismos. Num artigo de Sękowska encontramos ainda a definição seguinte: Neologizmy sa w języku warstwa względna, zwiąana $z$ dana epoka rozwoju języka; sq nieustabilizowane językowo, brak ich w słownikach objaśniających. Z biegiem lat albo następuje ich stabilizacja, albo wychodza z obiegu językowego (Sękowska 2012: 99). ${ }^{5}$

Geralmente, na neologia distinguem-se as fases que devem ser tomadas em consideração: a fase inicial, então o aparecimento de uma nova unidade lexical; aceitação ou rejeição desta unidade pela comunidade falante; processo de desneologização, relacionado com a dicionarização da palavra. Os falantes têm assim um papel muito importante na introdução de novos vocábulos, o papel hoje reforçado pelo emprego de meios de comunicação modernos, p.ex. as redes sociais e aplicações. Assim, o dicionário é, segundo Biderman (2002: 75), "um instrumento indispensável e imprescindível na fixação do léxico de uma língua escrita e literária.”

As novas realidades obrigam-nos a criar neologismos e tanto o português como o polaco, como todas as línguas, dispõem de vários processos de formação de novas palavras, com maior ou menor sucesso. São processos tais como neologia fonológica, processos autóctones dentro de próprios recursos linguísticos e a importação de elementos das outras línguas. ${ }^{6}$

5 Os neologismos formam numa língua um conjunto relativo, ligado à dada época no desenvolvimento da língua; são instáveis do ponto de vista linguístico, observa-se a sua ausência em dicionários enciclopédicos. Com o tempo, tornam-se estáveis ou caem no esquecimento (tradução nossa).

6 Em Guilbert (1975), encontramos quatro processos: formação onomatopaica, morfológica, semântica e por 
A neologia é um fenómeno natural, embora haja pessoas que se preocupam em preservar a língua no estado anterior. O neologismo, no início, pode parecer estranho, mas, em geral, a sua integração depende dos falantes de uma dada língua, que o criaram ou emprestaram do outro sistema linguístico, aparece numa época determinada e com objetivos determinados. Muitas das palavras hoje tratadas como neologismos podem integrar-se na língua de tal maneira que ninguém as perceberá como novas ou desconhecidas dentro de um prazo, que é, portanto, difícil de determinar. Estas palavras também podem cair em desuso, por serem, por exemplo, resultados da moda ou por pertencerem às girias que podem mudar de geração em geração. ${ }^{7}$ Os dicionários têm um papel importante neste caso: "A existência do termo novo [...] é confirmada por sua inserção no dicionário, certidão de nascimento, a partir da qual o termo deixa de ser neológico" (Carvalho 2001: 66).

Boulanger (1989) refere-se a um novo aspeto da pesquisa em neologia, observado na segunda metade do século XX: a neologia das áreas de especialidade ou terminológicas. A partir desse período, a neologia passou a ser estudada não apenas na língua mais geral, mas também nos textos relativos a diferentes áreas de especialidade; assim foram atribuídas ao conceito de neologia as seguintes atividades:

- processo prático de criação de novas unidades lexicais, na língua geral ou nas línguas de especialidade, por meio do recurso consciente ou inconsciente aos mecanismos de criatividade lexical habituais em uma língua;

- estudo teórico e aplicado relativo às inovações lexicais: os processos de criação, os critérios de reconhecimento, aceitabilidade e difusão de neologismos, os aspetos sociais e culturais da neologia;

- atividade institucional, organizada sistematicamente para coletar, registar, difundir e implantar as inovações lexicais, no âmbito concreto de uma política da língua;

- tarefa de identificação dos setores especializados novos ou recentes, ou com lacunas que necessitam de intervenção;

- relação com os dicionários, tanto gerais, unilingues, como específicos (dicionários de neologismos, de palavras selvagens, de empréstimos etc) (Boulanger 1989: 200-207). ${ }^{8}$

Correia (2005: 7) indica alguns princípios que deveriam caraterizar a criação dos neologismos, tais como a transparência de denominação, o respeito pela estrutura da língua de acolhimento, as probabilidades de acolhimento do termo proposto, a adequação ao vocabulário da especialidade em causa, a capacidade de constituir base de paradigmas derivacionais e/ou composicionais, a frequência de uso do termo.

Os neologismos aparecem em meios de comunicação de massa, sobretudo na imprensa "tradicional" e online; na nossa opinião, atualmente é o mundo virtual que fornece mais exemplos, é um

empréstimo. Na mesma obra, Guilbert apresenta outra classificação mais abrangente: la néologie phonologique, la néologie syntagmatique, la néologie sémantique et la néologie d'emprunt (1975: 59).

7 Algumas fontes sublinham a importância da adaptação da palavra, para que seja identificável para a comunidade falante, e indicam que a sua frequência de uso provocará as transformações gráficas. Portanto, como veremos no nosso estudo, há muitíssimas palavras que tinham sido aceites pelas comunidades falantes, mas apesar da sua dicionarização, não alteraram a sua forma gráfica ( $t$-shirt, jeans).

8 http://piwik.seer.fclar.unesp.br/alfa/article/view/3992/3662 (consultado em 16.04.2021). 
lugar onde se vê uma grande criatividade neológica dos usuários, das pessoas que não só escrevem e publicam na Internet, mas também as que colocam os comentários, entram em interação com os autores dos textos, refletindo uma língua viva, sempre em mudança (Jabłonka 2016: 39).

O que é diferente, atrai ou parece perigoso, não só na língua, mas os neologismos fazem parte do processo da evolução de cada língua. A realidade, o mundo que nos rodeia, mudam constantemente, alguns fenómenos, objetos, produtos e os seus nomes caem em desuso, por outro lado, sempre aparecem fenómenos que exigem de ser nomeados, como se tem observado também nos últimos tempos desde que o estado de pandemia foi declarado.

Resumindo, parece possível constatar que o sistema lexical é uma parte da linguagem mais suscetível às mudanças ocorrentes sob a influência dos fatores extralinguísticos, nomeadamente, acontecimentos importantes de caráter político-social que conduzem a alterações graves na sociedade, alterações económicas ou mudanças de sistema de valores na sociedade. Com certeza, o ano 2020 vai passar para a história mundial como o ano de pandemia do coronavírus que teve grande impacto no funcionamento de quase todos os países do mundo e na vida quotidiana dos seus habitantes. Por isso, é natural que a pandemia tenha uma grande influência também nas línguas e que tenha alterado a maneira de nomear novas emoções; também tem provocado processos de lidar com o stress e o medo através de jogos de palavras e neologismos divertidos. Os fenómenos apresentados a seguir inscrevem-se, na nossa opinião, na tendência geral de formação de neologismos ocasionais, de reestruturação de significados de lexemas ja existentes no sistema linguístico, de criação constante de novos termos, também profissionais.

\section{Seleção e apresentação de dados}

\subsection{Dados gerais}

No final de 2019, na cidade de Wuhan, província de Hubei, na China, surgiu um vírus do tipo Sars-CoV-2, determinado no início como "o novo coronavírus", que gerou uma nova doença chamada de COVID-19, uma infeção respiratória muito grave. O seu impacto foi tão forte que a OMS declarou o estado de pandemia em 11 de março de 2020, o que alterou significamente vários aspetos de vida dos seres humanos do mundo inteiro. O vírus SARS-CoV-2 em polaco foi inicialmente denominado nos meios de comunicação como "vírus chinês" ou "vírus de Wuhan". Portanto, estes nomes foram criticados pelo governo chinês como politicamente incorretos. Numa das edições da revista "Newsweek" na Polónia apareceu também o nome "italowirus" relacionado com o grande número de infeções na Itália no início de março de 2020 (Kuligowska 2020: 112).

O corpus que conseguimos reunir provém sobretudo de diferentes páginas de Internet com ajuda de motor de busca Google e Google Scholar. Os lexemas encontrados demonstram a situação complicada e difícil com a qual o mundo inteiro tem andado a lidar há muitos meses e a nova realidade em que vivemos, alterada pelo coronavírus.

Para estabelecer o nosso corpus, um dos critérios principais foi o temático: procuramos os textos relacionados com a pandemia e o coronavírus, comparando-o com as fontes lexicográficas. O próprio termo "coronavírus / koronawirus" tem origem latina (coronaviridae) e refere-se ao grupo inteiro de coronavírus, portanto, o seu uso foi restringido ao representante chamado de 
SARS-CoV-2 (no início 'novo coronavírus / nowy koronawirus'), gerador da infeção COVID-19 (nome proveniente do inglês - CO - corona, VI - virus, D - disease). O componente "corona- / korona-" relaciona-se com a estrutura do vírus que parece possuir uma coroa. Portanto, o significado básico do componente mencionado tem mesmo a ver com a palavra "coroa / korona" (distintivo de poder régio, destinado a ornar a cabeça). Em polaco, usa-se bastante a forma abreviada "korona" que substitui o nome completo do vírus (em português, usa-se também 'corona'); às vezes, em polaco, esta forma é usada também como diminutiva (porém, koronka tem outros significados tais como: renda; um tipo de oração ${ }^{9}$ ).

Um dos primeiros assuntos que devemos tomar em consideração é a função do componente "korona / corona" em palavras compostas polacas e portuguesas:

Korona - pierwszy człon wyrazów złożonych wskazujący na ich związek znaczeniowy z pandemiq koronawirusa SARS-CoV-2 (Corona - primeiro componente de palavras compostas que indica a sua ligação semântica com a pandemia de coronavírus SARS-CoV-2), p.ex. koronabiznes, koronaferie, koronakryzys, koronatransport, koronazakupy, coronaférias, coronanoiva, coronafobia. ${ }^{10}$ A título de exemplo, vejam-se as frases:

Obawa przed \#koronawirus narasta. W sprzedaży brakuje żeli antybakteryjnych i maseczek ochronnych. W sieci kwitnie koronabiznes. Na strachu ludzi żeruja nieuczciwi sprzedawcy (twitter.com). Szał koronazakupów dotarł do Szwecji. Z półek znikają makarony, gotowe pótprodukty i produkt nr jeden na calym świecie... papier toaletowy (facebook.com). Narracja pierwszych tygodni koronakryzysu w USA było zaprzeczanie jego istnieniu, potem minimalizowanie jego konsekwencji (faktyimity.pl).

Bo potem my wracamy do domów, do rodzin, bo system szwankuje, bo godziny czekania na koronatransport, dni czekania na koronawyniki (edziecko.pl). ${ }^{11}$

Coronavírus: um grupo de vírus capaz de causar doenças em humanos e animais. O novo Coronavírus, conhecido como SARS-CoV2, causa a doença Covid-19. São da mesma família o SARS-CoVe o MERS-CoV, além de outros coronavírus que causam normalmente resfriados comuns. Sua estrutura é formada por micro espinhos quando vista ao microscópio eletrônico, que se parecem muito com uma coroa. É daí que vem o nome de "corona". 12

A palavra koronawirus foi escolhida Palavra do Ano 2020 na Polónia, ganhando o primeiro lugar na votação dos internautas e dos linguistas polacos. ${ }^{13}$

Outra questão muito importante é que o componente corona-/korona- é bastante produtivo tanto em português como em polaco formando novos lexemas, também com componentes estrangeiros, sobretudo de origem inglesa (coronaparty, koronachallenge). No entanto, observando

9 Terço da misericórdia.

$10 \mathrm{https} / /$ nowewyrazy.pl/haslo/korona.html?pdf=1 (consultado em 08-04-2021).

11 https://nowewyrazy.pl/haslo/korona.html?pdf=1(consultado em 08-04-2021).

12 https://www.accamargo.org.br/sobre-o-cancer/noticias/covid-19-um-glossario-com-22-termos-para-voceconhecer (consultado em 08-04-2021).

13 https://www.uw.edu.pl/wyniki-plebiscytu-slowo-roku-2020/ (consultado em 24-04-2021). 
as tendências gerais no processo neológico, parece-nos possível considerar que muitas das inovações citadas nos capítulos seguintes são sobretudo ocasionais e o seu futuro fica incerto depois do fim da pandemia. Portanto, alguns neologismos com este componente já ficaram dicionarizados ou se encontram nos glossários que apresentamos a seguir, o que podia sugerir a sua futura presença mais estável no léxico das duas línguas estudadas.

\subsection{O componente korona- nos neologismos em dicionários e páginas web em polaco}

Neste capítulo pretendemos apresentar alguns exemplos de neologismos polacos formados com o componente korona-. Grande número de lexemas citados das fontes polacas e dos artigos científicos relacionados com este assunto evidencia uma forte influência do lexema koronawirus no léxico polaco. Antes de iniciar a investigação, verificámos a presença desse lexema em Dicionários de Língua Polaca. No Słownik Języka Polskiego PWN o lexema não foi encontrado no dia da pesquisa. ${ }^{14}$ Ao contrário, a sua definição já se encontra no Wielki słownik języka polskiego onde lemos a seguinte definição: wirus majacy otoczkę białkowa z wypustkami przypominajacymi koronę, wywołujacy choroby układu oddechowego u ludzi i różne choroby u zwierząt. ${ }^{15} \mathrm{O}$ dicionário contém também informações sobre a origem do lexema e diferentes usos em frases desde 2004 até à atualidade. ${ }^{16}$ Uma breve definição está também presente no Słownik Języka Polskiego (SJP): patogen odpowiedzialny za infekcje układu oddechowego, atakujacy głównie ssaki i ptaki; portanto, não se observa nenhuma relação com a situação atual (segundo o dicionário, o coronavírus ataca principalmente aves e mamíferos). ${ }^{17}$ Contudo, vale a pena mencionar que os coméntarios acerca da definição colocados pelos internautas são todos dos anos 2020 e 2021, o que nos permite ver o interesse crescente pela pesquisa do lexema koronawirus em dicionários desde o surgimento da pandemia e verificar algumas sugestões de atualização do termo tendo em conta a situação atual.

Quanto aos neologismos polacos com o componente korona-, alguns já foram estudados em publicações recentes cujos dados mais detalhados se encontram nas referências bibliográficas. Muitos exemplos são citados p. ex. no artigo de Kuligowska (2020), onde encontramos uma lista muito rica de neologismos dos quais escolhemos alguns para completar o presente estudo. Como podemos ler no artigo mencionado, uma pessoa assustada pelo coronavírus e que cumpre muito rigorosamente todas as recomendações oficiais é determinada como korona-niewolnik (corona-escravo). ${ }^{18}$ Outros neologismos polacos formados com o componente korona- são p.ex.: koronarabuś (ladrão que rouba aproveitando as condições pandêmicas), koronaszwaczka (costureira voluntária que cose máscaras), koronacelebryta (alguém que se tornou conhecido por ser infetado pelo coronavírus ou uma pessoa famosa infetada). Grande parte de novos vocábulos é relacionada com os comportamentos dos membros da sociedade durante a pandemia (p.ex. koronaoptymizm - corona-otimismo, koronalans - ações de caridade realizadas

15 https://www.wsjp.pl/index.php?id_hasla=99350\&ind=0\&w_szukaj=koronawirus (consultado em 24-04-2021).

16 https://www.wsjp.pl/do_druku.php?id_hasla=99350\&id_znaczenia=5241113 (consultado em 24-04-2021).

17 https://sjp.pl/koronawirus (consultado em 24.04.2021).

18 É imprescindível mencionar que ainda não existe a unanimidade quanto à grafia das palavras compostas com "korona / corona" tanto em português como em polaco. Alguns lexemas são escritos com hífen, outros não. 
apenas para se tornar famoso, korona-plucie - ato de cuspir em outras pessoas para assustá-las com uma infeção possível, koronadepresja - corona-depressão; encontramos também nomes de eventos organizados durante a pandemia (korona-grill - corona-churrasco, korona-party ${ }^{19}$, korona-wesele - corona-boda) e de atividades de serviço de saúde (korona-ambulans - corona-ambulância, koronatest - corona-teste) A mesma autora cita também vários neologismos relacionados com as finanças tais como koronarecesja (corona-recessão), koronaceny (corona -preços), assim como diferentes nomes relacionados com os meios de comunição, como p.ex. koronanews (coronanews), koronamem (corona-meme), koronanewsletter, korona-dziennik (corona-diário) (Kuligowska 2020: 116-117). Por sua vez, Cierpich-Kozieł (2020) menciona ainda os lexemas tais como koronaściema e koronabzdura (ambos podiam ser traduzidos como corona-mentira), koronaalert (corona-alerta), koronachallenge (situações em que os jovens mostram na rede que não têm medo do coronavírus), koronachaos (corona-caos), koronaśmieci (corona -lixo) e muitas outras (Cierpich-Kozieł 2020: 5-9).

Alguns lexemas relacionados com o coronavírus já se encontram dicionarizados, por isso, a seguir apresentamos definições em dicionários polacos disponíveis on-line.

\section{(1) Koronaferie ${ }^{20}$}

Definicja: Okres przerwy w nauce i nauczania zdalnego zwiąanych z epidemią koronawirusa. Dodano: 3.11.2020. Słowo zgłoszone w plebiscycie na Młodzieżowe Słowo Roku 2020 (trata-se do período de encerramento de estabelecimentos de ensino primário e secundário devido à pandemia; verificámos na pesquisa online que a palavra tinha 35600 resultados no motor de busca Google; no dicionário Słownik Języka Polskiego on-line foi adicionada no dia 3 de novembro de 2020 e logo se tornou candidata para o voto no concurso "Palavra do Ano 2020 dos Adolescentes"). ${ }^{21}$

Exemplos de emprego:

Spraw, by tzw. "koronaferie" minęly przyjemnie i odpowiednio wykorzystaj ten czas. ${ }^{22}$ Widze pewnego rodzaju zadowolenie, traktowanie tego pierwszego tygodnia jako "koronaferii" czy "koronaurlopu". ${ }^{23}$

Kwarantanna to nie "koronaferie"! Ostrzegamy przed korzystaniem z boisk, siłowni plenerowych, placów zabaw. ${ }^{24}$

19 Também aparece nas fontes eletrónicas a forma "koronawirus party", que encontramos p.ex. em https://www. polityka.pl/tygodnikpolityka/ludzieistyle/1961694,1,korona-na-jezyku-czyli-pandemia-w-polszczyznie.read (consultado em 26-04-2021).

20 Vale a pena esclarecer que o lexema ferie, em polaco, em geral refere-se ao período de descanso de duas semanas para alunos em janeiro/fevereiro. Por isso, o equivalente polaco mais adequado para o termo 'coronaférias' em português é, na nossa opinião, koronawczasy ou também koronaurlop.

21 https://sjp.pwn.pl/mlodziezowe-slowo-roku/haslo/koronaferie;6949159.html (consultado em 28-03-2021).

22 https://www.travelplanet.pl/blog/koronaferie-7-pomyslow-na-to-co-robic-w-czasie-kwarantanny/ (consultado em 23-03-2021).

23 https://www.tygodnikpowszechny.pl/koronaferie-wkrotce-sie-skoncza-162826 (consultado em 23-03-2021).

24 https://www.pyskowice.pl/kwarantanna-to-nie-koronaferie-ostrzegamy-przed-korzystaniem-z-boisk-silowniplenerowych-placow-zabaw.html (consultado em 23-03-2021). 
Esse termo aparece também no dicionário de novas palavras criado pelos especialistas da Universidade de Varsóvia ${ }^{25}$, em que são colocados os neologismos mais frequentes (koronaferie: okres prewencyjnego zamknięcia szkół z powodu zagrożenia koronawirusem postrzegany jako wakacje i okazja do rozrywki - período de fechamento preventivo de escolas devido ao perigo de infeção por coronavírus, tratado como verdadeiras férias e como pretexto para diversão). Exemplos de uso: Jako Młodzieżowa Rada Miasta apelujemy do wszystkich naszych rówieśników, że nie sa to koronaferie. (brzeg24.pl). ${ }^{26}$

Outro exemplo que chamou a nossa atenção e aparece também no supra citado dicionário, é

(2) koronaświrus - o neologismo resultante do jogo de palavras "wirus" (vírus) e "świrus" (maluco); uma pessoa que nega a pandemia costuma chamar o coronavírus de "coronamaluco". Em geral, este termo é usado pelas pessoas que não acreditam na existência do coronavírus e consideram falsas todas as informações acerca da pandemia; na sua opinião, trata-se de uma estratégia de grandes empresas multinacionais que se enriquecem provocando o medo da pandemia. Exemplos:

Pandemia to wymyst dla mięczaków? Nie ma koronaświrusa? To zwykła grypa? Przyjedź i przekonaj się sam. Jeśli się nie boisz, pomóż blisko 100 zakażonym w Nowym Sączu.

Tak z ciekawości, co z tym koronaświrusem? Co z tym COVID-em?

Kto zakończy koronaświrusa? Epidemia zabiła wolność w Polsce?27

O termo seguinte definido no dicionário supra citado tornou-se muito popular nos meios de comunicação polacos; é o caso de:

(3) koronasceptyk (coronacético) - uma pessoa que nega a pandemia, também chamada de antycovidowiec ("anticovidista"). Exemplos:

I choć swoich teorii nie potrafia udowodnić, koronasceptycy aktywnie sprzeciwiaja się epidemicznym zarządzeniom rządu.

W szpitalu wojewódzkim im. J. Gromkowskiego we Wrocławiu jest obecnie leczonych dwóch koronasceptyków. [...] Jedna osoba jest na granicy śmierci, a druga może nie umrze - mówi lekarz. Koronasceptyk namawiał $w$ szkole do zdjęcia maseczek. ${ }^{28}$

Selecionámos ainda o lexema:

(4) koronacelebryta (corona-celebridade): uma pessoa famosa infetada pelo coronavírus ou famosa somente graças à infeção. Exemplos:

Odniosę się jedynie do naszego lokalnego koronacelebryty z podlubelskiej gminy - rodzina boi się linczu, odpowiedzialności, więc lataja po gazetach i opowiadają, jak to chcieli się przebadać, ale się nie dało. [...] 
Co raz więcej różnej maści koronacelebrytów. Przerażajace, jak wiele osób próbuje ugrać coś dla siebie pod płaszczykiem "dobra."

Como mais um termo bastante frequente, aparece o lexema:

(5) koronaczasy - período de pandemia de SARS-CoV-2 ("corona-tempos").

Exemplos:

Niby nic takiego, a jednak w tych przedziwnych koronaczasach wszystko jakoś bardziej cieszy. Wszystko lepiej smakuje

Nastały koronaczasy... Większość z nas tym żyje. Tylko czy myślenie i czytanie artykułu nr 10000000 o wirusie coś daje...? ?30 $^{30}$

(6) Koronanews - notícias sobre o coronavírus.

Okrutnie smutna wiadomość, która utonie w morzu koronanewsów. A Penderecki powinien być pamiętany czy wręcz przypomniany wielu osobom.

Bez zasiegu i internetu, $z$ dala od wszystkich niesprawdzonych, wyssanych z palca koronanewsów. Nie, nie umniejszam pandemii. Ale jestem potwornie zmęczona ilością i absurdem fake newsów. ${ }^{31}$

(7) Korontanna - quarentena causada pela infeção com o coronavírus.

Wczoraj poczułem się troche przeziębieniowo i postanowiłem zrobić sobie dobrowolna korontanne, przez co jedyna osobą z którą się dzisiaj zobaczyłem, był pan dostawca pizzy. ${ }^{32}$

(8) Koronamowa - a fala dos tempos do corona (corona-fala); neologismos relacionados com a pandemia do coronavírus. ${ }^{33}$ Esse neologismo indica que o coronavírus teve grande impacto no léxico e provocou o surgimento de diferentes novas designações usadas pelos falantes. ${ }^{34}$

Observando todos os lexemas citados nesse capítulo, é possível considerar que se trata de formas expressivas que servem para determinar a realidade que nos rodeia, sendo palavras-testemunhas de uma época excecional. Repara-se também na tendência de nacionalização e globalização na formação dos neologismos com o componente korona- que se espalham muito rapidamente graças aos novos meios de comunicação. Vale a pena acrescentar que um dos linguistas mais conhecidos na Polónia, Jerzy Bralczyk, não é a favor do uso de muitos neologismos com o componente korona-, no entanto, reconhece que se trata de uma palavra muito produtiva e de fácil composição com outros componentes. ${ }^{35}$

29 https://nowewyrazy.uw.edu.pl/haslo/koronacelebryta.html (consultado em 23-03-2021).

30 https://nowewyrazy.uw.edu.pl/haslo/koronaczasy.html (consultado em 24-03-2021).

31 https://nowewyrazy.uw.edu.pl/haslo/koronanews.html (consultado em 23-03-2021).

32 https://nowewyrazy.uw.edu.pl/haslo/korontanna.html (consultado em 23-03-2021).

33 https://nadwyraz.com/blog/blog-ubierz-sie-w-slowa/koronamowa-czyli-neologizmy-powstale-w-2020-r-wzwiazku-z-pandemia-slownik-slow-covidowych (consultado em 28-04-2021).

34 https://polszczyzna.pl/koronamowa-czyli-neologizmy-powstale-w-2020-r-w-zwiazku-z-pandemia-slownik-slowcovidowych/ (consultado em 28-04-2021).

35 Nie jestem zwolennikiem nadmiernego używania takich różnych 'koron '”- zastrzega językoznawca i podkreśla, że takie sformułowania dość mocno go irytują, bo ich używanie jest upraszczaniem rzeczywistości. Wolałby on, żeby to było jakoś 


\subsection{O componente corona- nos neologismos em dicionários e páginas web em português}

Antes de passar à apresentação de exemplos selecionados de dicionários e de páginas de Internet em português, é preciso mencionar que desde o surgimento da pandemia têm aparecido várias iniciativas e projetos de criação de glossários relacionados com esta temática, como p.ex. o Glossário Colaborativo COVID-19 (Lexonomy) da CLUNL da Faculdade de Ciências Sociais e Humanas da Universidade Nova; O léxico da covid-19 do site "Ciberdúvidas da Língua Portuguesa" ${ }^{6}$; Glossário terminológico da pandemia 2020: os termos de prevenção, sintomas e tratamento sobre o COVID-19 da Universidade de Brasília; Dicionário Enciclopédico do Novo Coronavírus da Universidade Federal de Santa Maria. As iniciativas mencionadas demonstram que a pandemia do coronavírus teve grande impacto no léxico português, tal como no léxico polaco.

Passando à dicionarização do lexema 'coronavírus', devemos observar algumas divergências entre os dicionários consultados. No Dicionário Priberam em linha encontramos a seguinte definição:

coronavírus $\mid$ n. m. 2 núm., co·ro·na·ví·rus (latim corona, -ae, coroa + vírus)

nome masculino de dois números

[Biologia, Medicina] Designação dada a vários vírus com ARN como material genético, cuja forma lembra a de uma coroa, que são causa comum de infecções respiratórias leves a moderadas, mas também da pneumonia atípica grave.

Palavras relacionadas:

corona, alfacoronavírus, betacoronavírus, deltacoronavírus, gamacoronavírus, pneumonia, coronavirologia.

Esta palavra em blogues: CORONAVÍRUS , SOCIEDADE E DIREITO: QUESTÕES DE MORTE E DE VIDA Paulo Ferreira da Cunha...

em NOVA ÁGUIA: REVISTA DE CULTURA PARA O SÉCULO XXI

...do pan(ic)o, no que é tão manipulado e manipulador: 10 de março de 2020 Coronavírus: o testemunho de um virologista Bruno CANARD Chamo-me Bruno Canard, sou director de...

Em anónimo séc.xxi:

...internado no hospital em 1 de março por complicações causadas pela infecção pelo novo coronavírus

Em Caderno B:

Dândara Genelhú --MidiaMax Cada vez mais famílias dividem a dor de estarem infectadas pelo coronavírus em Mato Grosso do Sul.. ${ }^{37}$

opisane. Trzeba jednak przyznać, że samo słowo 'korona 'dość dobrze do tego się nadaje - jest poręczne i łatwo się przykleja do innych słów. https://naukawpolsce. pap.pl/aktualnosci/news,82594,prof-bralczyk-mam-nadzieje-ze-wiele-slow-zwiazanych-z-epidemia-nie-zostanie (consultado em 28-04-2021).

36 Este glossário chega assim, na presente atualização, a mais de 1110 entradas, reunindo palavras e locuções postas em circulação pelos media em português, no registo diário das graves repercussões nacionais e internacionais da pandemia de covid-19.' in Ciberdúvidas da Língua Portuguesa, https:/ciberduvidas.iscte-iul.pt/aberturas/1110-entradas-no-lexicoda-covid-19-o-verbo-subir-os-ciganos-de-portugal-e-a-relacao-poesia-musica/2629 (consultado em 12-04-2021).

37 coronavírus in Dicionário Priberam da Língua Portuguesa (em linha), 2008-2021, https://dicionario.priberam.org/ coronav\%C3\%ADrus (consultado em 24-03-2021). 
A definição do lexema 'Coronavírus' no Dicionário Infopédia de Porto Editora é bastante parecida:

\section{coronavírus}

co.ro.na.ví.rus; nome masculino de 2 números

MEDICINA designação comum, extensiva a qualquer um dos vírus da família Coronaviridae, capazes de infetar animais e humanos causando doenças respiratórias e digestivas (entre as que afetam o ser humano, contam-se a COVID-19, a síndrome respiratória do Médio Oriente ou a síndrome respiratória aguda grave) e que, observados ao microscópio, apresentam uma morfologia característica que recorda a forma de uma coroa. ${ }^{38}$

Entre as palavras derivadas encontramos no mesmo dicionário os lexemas 'coronafobia' e 'coronafóbico':

(1) Coronafobia: "nome feminino. 1. ansiedade relacionada com a pandemia da COVID-19; 2. medo patológico de ser contaminado pelo coronavírus causador da COVID-19."

(2) Coronafóbico: "adjetivo 1. relativo a coronafobia (ansiedade relacionada com a pandemia da COVID-19); 2. que sofre de medo patológico de ser contaminado pelo coronavírus causador da COVID-19 (de coronafobia+-ico)."39

No mesmo dicionário encontramos ainda o lexema:

(3) 'coronaviral': "adjetivo de 2 géneros; 1 . relativo a coronavírus 2. causado por coronavírus."

A seguir, passemos à definição encontrada no dicionário brasileiro online Dicio.com.br:

substantivo masculino plural [Medicina] Família de vírus (Cov) que provoca variadas doenças em animais e pessoas, especialmente infecções respiratórias, sendo a sua manifestação mais severa conhecida como Síndrome Respiratória Aguda Grave (SARS-Cov). expressão Novo Coronavírus. Novo tipo de vírus pertencente à família dos Coronavírus que, conhecido como SARS-CoV-2, causa uma síndrome respiratória aguda, grave e altamente contagiosa, chamada Covid-19. Pandemia de Covid-19. Epidemia mundial da síndrome respiratória aguda e grave causada pelo Novo Coronavírus.Etimologia (origem da palavra coronavírus). Por influência do inglês coronavirus, pelo latim corona, ae "coroa" + vírus. ${ }^{40}$

No dia da realização da pesquisa, a definição do termo ainda não foi encontrada no site do Dicionário Michaelis online (“O verbete não foi encontrado. Você quis dizer: carnivoraz"). ${ }^{41}$

38 coronavírus in Dicionário infopédia da Língua Portuguesa (em linha). Porto: Porto Editora, $2003-2021$. (consultado em 07-04-2021).

39 coronafóbico in Dicionário infopédia da Língua Portuguesa (em linha). Porto: Porto Editora, $2003-2021$. (consultado em 07-04-2021).

40 https://www.dicio.com.br/coronavirus/ (consultado em 07-04-2021).

$41 \mathrm{https} / /$ michaelis.uol.com.br/busca? $\mathrm{r}=0 \& \mathrm{f}=0 \& \mathrm{t}=0$ \&palavra=Coronav\%C3\%ADrus (consultado em 24-03-2021). 
No dicionário online https://www.lexico.pt/ encontramos no dia da consulta apenas dois exemplos de uso, sem definição, portanto, com datas de introdução anteriores ao surgimento da pandemia:

\section{"Exemplos com a palavra Coronavírus}

É a sexta morte associada ao novo coronavírus, que afecta de forma grave as vias respiratórias. O doente morreu no domingo de manhã. Público, 19.02.2013

Estudo mostra que novo coronavírus está bem adaptado às pessoas, mas Organização Mundial de Saúde diz que é menos transmissível do que vírus SARS que causou centenas de morte na China há uma década. Público, 20.02.2013”"42

O site https://ciberduvidas.iscte-iul.pt/artigos/rubricas/idioma/o-lexico-da-covid-19/405943 apresenta uma grande variedade de lexemas relacionados com o coronavírus e a pandemia em geral, entre os quais se encontram os termos com o componente corona- tais como: 'coronabonds; coronacéticos; coronafobia; coronation; coronado; coronaro; CoronaVac; coronavir; coronavírus; coronavírus ao minuto; coronavírus humano. ${ }^{34}$ Vejamos alguns termos cujas definições encontramos em fontes eletrónicas.

(4) Coronabonds - Podem ser definidos como dívidas mútuas. Se traduzirmos para Português, ficaríamos com algo do género "Obrigações (bonds) Corona".

"Os coronabonds, defendidos por alguns Estados europeus, constituem emissões conjuntas de dívidas que seriam assumidas por todos os países da zona euro. O Banco Central Europeu ao ser o principal comprador podia exigir taxas de juro mais baixas do que certos países estão habituados a pagar, Portugal inclusive." ${ }^{45}$

No artigo publicado na revista Visão "Os tempos do corona" encontramos alguns lexemas novos em português, com respetivas definições, dentre os quais citamos apenas os exemplos com o componente corona-:

(5) “Coronado (Coronavirus + lixado): Estar pelos cabelos, ou com a cabeça cheia, seja pelo caráter monotemático das conversas ou devido à sensação de impotência face aos estragos da crise;

42 https://www.lexico.pt/coronavirus/ (consultado em 24-03-2021).

43 "O glossário O léxico da covid-19 tem um triplo objetivo: 1) O registo lexical dos termos e expressões (neologismos e, até, mero jargão, inclusive) marcantes do período da pandemia do novo coronavírus, com os respetivos significados e contextos, dando particular atenção àqueles que se revelam mais densos ou mais afastados dos conhecimentos do falante comum de português, e sempre com a devida remissão a fontes científicas (caso dos termos médicos) e autorais (v.g., frases de organismos e autoridades sanitárias e governamentais); 2) A contribuição, em simultâneo, para "memória futura", desta nova realidade vocabular na língua portuguesa, que motivou uma forte dinâmica lexical; 3) A criação de um corpus alargado do léxico especificamente relacionado com as várias áreas da pandemia, com vista a possibilitar futuras reflexões e/ou investigações linguísticas. https://ciberduvidas.iscte-iul.pt/artigos/rubricas/idioma/o-lexico-da-covid-19/4059 (consultado em 07-04-2021).

44 in Ciberdúvidas da Língua Portuguesa, https://ciberduvidas.iscte-iul.pt/artigos/rubricas/idioma/o-lexico-dacovid-19/4059\# (consultado em 07-04-2021).

45 https://www.jpn.up.pt/2020/04/07/covid-19-as-palavras-que-entraram-no-nosso-vocabulario/ (consultado em 24-03-2021). 
(6) Coronaro (Coronavirus + Bolsonaro): A célebre criatividade dos brasileiros, ou seja, daqueles que não alinham com o Presidente que diz, entre outras ligeirezas, "é só uma gripezinha." 46 A pesquisa realizada na Internet possibilitou ainda a verificação do uso dos seguintes termos:

(7) Coronials / coronialls: "geração que nascerá durante ou como fruto da pandemia; o termo tem relação com a palavra millenials (geração nascida entre 1980 e 1995)." ${ }^{47}$

(8) Coronacético: negacionista do coronavírus: "Manifestação de coronacéticos degenera em confrontos em Barcelona", "Coronacéticos agitam debate", "Coronacéticos no mundo desde a extrema direita aos antivacinas".

(9) Coronga: "(Uso Popular) A palavra Coronga tem sido usada popularmente e com sentido irônico para se referir ao coronavírus." ${ }^{48}$ Forma debochada de se referir ao novo coronavírus, que também virou só "corona." 49

Comparando os lexemas citados nesse subcapítulo com os exemplos polacos, é possível observar que se trata de processos de formação de neologismos muito parecidos que servem para responder às necessidades do "novo normal", quer dizer, um novo padrão de vida, de normalidade, causado pela pandemia. Os neologismos com o componente corona- tornam-se populares devido às mudanças ocorrentes no mundo inteiro e propagam-se com muita facilidade na Internet.

\section{Conclusões}

Os neologismos selecionados para os objetivos do presente estudo referem-se aos fenómenos internacionais, relacionados com novas tecnologias; os neologismos ocasionais são em geral efémeros, usados sobretudo para chamar a atenção das pessoas. Todos os exemplos apresentados tornam visível que as mudanças lexicais relacionadas com o aparecimento do novo coronavírus e com a pandemia são muito rápidas e demonstram uma grande criatividade dos falantes de português e de polaco. Distinguimos entre os neologismos com o componente korona- / corona-: empréstimos do inglês, tais como 'coronials' (em inglês usa-se também a designação the Coronavirus Generation) ou 'coronabonds'; amálgamas (p.ex. coronado, de coronavírus + lixado;), híbridos (p.ex. koronachallenge, de koronawirus + challenge) ou contaminações ('coronga', de corona + corongo; korontanna, de koronawirus + kwarantanna; koronaświrus, de koronawirus + świrus). Graças aos novos meios de comunicação, à Internet e às redes sociais novos vocábulos transmitem-se nas comunidades falantes e o seu uso é atestado já em dicionários. A comparação entre o polaco e o português permite-nos também observar a internacionalização de novos vocábulos, visível nos materiais apresentados e nos processos de formação de novas palavras, tais como coronaparty

$46 \mathrm{https} / /$ visao.sapo.pt/atualidade/sociedade/2020-05-16-vamos-la-falar-em-covides-as-palavras-que-a-pandemiacolocou-na-nossa-boca/ (consultado em 08-04-2021).

47 https://www.diariodaregiao.com.br/cidades/2020/05/1193621-pandemia-do-coronavirus-traz-a-tona-novaspalavras-e-termos.html (consultado em 08-04-2021). Quanto à dupla grafia: repare-se que a grafia do lexema no referido site não é correta (coronialls), talvez tenha sido influenciada pelo anglicismo, no entanto, a forma correta devia ser coronials, comummente usada nas páginas web em português.

48 https://www.dicio.com.br/coronga/ (consultado em 08-04-2021).

49 https://vejario.abril.com.br/cidade/girias-pandemia/ (consultado em 08-04-2021). 
/ koronaparty, coronacético / koronasceptyk, coronafobia / koronafobia. Trata-se de um componente muito produtivo, sobretudo na formação de substantivos em ambas as línguas estudadas; selecionámos também alguns adjetivos, portanto, não são tão numerosos. Com certeza, é um processo que tem estado a decorrer todo o tempo, desde março de 2020, então, os resultados definitivos desse processo neológico só serão visíveis no futuro. Sem dúvida, o ano 2020 e provavelmente também 2021 serão lembrados como o tempo de doença, de medo e de crise em vários setores de economia. Todos esses aspetos se refletem também nas línguas que se enriqueceram com novas unidades lexicais relacionadas com a luta contra o coronavírus e a vida durante a pandemia.

Resumindo, observemos que com o coronavírus surgiram novos termos médicos, económicos e administrativos usados na comunicação e, sobretudo, termos coloquiais usados pelos falantes na nova realidade e termos ocasionais, expressivos e criados pelos falantes para aliviar o stress da vida quotidiana nos tempos difíceis. Torna-se importante conhecer estes novos termos, pois "procurar conhecer o léxico de uma língua a partir do conhecimento do léxico dos falantes implica compreender o que se passa nessa dimensão" (Villalva, Silvestre 2014: 23). Depois de algum tempo, observaremos qual dessas inovações ficará no léxico e quais serão esquecidas depois do fim da pandemia.

\section{Referências bibliográficas}

Alves, I. M. (1994). A integração dos neologismos por empréstimo ao léxico português. ALFA, 28, 119-126. Antunes, I. (2007). Muito além da gramática; por um ensino de línguas sem pedras no caminho. São Paulo: Parábola Editorial.

Barbosa, M. A. (1989). Léxico, produção e criatividade: processos do neologismo, 2ed. São Paulo: Global Editora.

Bechara, E. (2009). Moderna gramática portuguesa. 37a ed. Rio de Janeiro: Nova Fronteira.

Biderman, M. T. C. (2001). Fundamentos da Lexicologia. In Teoria linguística: teoria lexical e computacional (pp. 99-155). São Paulo: Martins Fontes.

Boulanger, J. C. (1989). Lexicographie et politique langagière: l'exemple français des avis officiels. In F. J. Hausmann et al., Wörterbücher/Dictionnaires/Dictionaries (vol 1) pp. 46-62). Berlim-Nova York: W. de Gruyter.

Cabré, M. T. (1993). La terminología: teoría, metodología, aplicaciones. Barcelona: Antártida.

Cagliari, L. C. (1999). A ortografia na escola e na vida. In G. Massini-Cagliari, \& L. C. Cagliari (Orgs.), Diante das letras: a escrita na alfabetização. Campinas, SP: Mercado de Letras.

Carvalho, N. (1984). Neologismo: o que é neologismo. São Paulo: Brasiliense.

Chaciński, B. (2020). Korona na języku, czyli pandemia w polszczyżnie. <https://www.polityka.pl/tygodnikpolityka/ludzieistyle/1961694,1,korona-na-jezyku-czyli-pandemia-w-polszczyznie.read>

Ciberdúvidas da Língua Portuguesa. O Léxico da Covid. <https://ciberduvidas.iscte-iul.pt/artigos/rubricas/ idioma/o-lexico-da-covid-19/4059>

Cierpich-Kozieł, A. (2020). Koronarzeczywistość - o nowych złożeniach z członem korona- w dobie pandemii. Język Polski, C/4 (em formato PDF), 102-117.

Correia, M.; \& Lemos, L. S. P. (2005). Inovação lexical em português. Lisboa: Ed. Colibri. 
Correia, M.; \& Barcellos Almeida, G. M. de (2012). Neologia em português. São Paulo: Parábola.

Ferraz, A. P. (2007). Neologismos na publicidade imprensa: processos mais frequentes no português do Brasil. In A. N. Isquerdo, \& I. M. Alves (Orgs.), As ciências do léxico: lexicologia, lexicografia, terminología (vol. 3). Campo Grande: Humanitas.

Guilbert, L. (1975). La creativité lexicale. Paris: Librairie Larousse.

Jabłonka, E. (2016). Introdução das unidades lexicais estrangeiras no português atual. Estudo baseado em blogues femininos portugueses e brasileiros. Lublin: Wydawnictwo UMCS.

Kuligowska, K. (2020). Język w czasach zarazy. O wpływie pandemii na system leksykalny języka polskiego i rosyjskiego. Acta Polono-Ruthenica, XXV, 3, 109-126.

Lexicovid-19. Dicionário Enciclopédico do Novo Coronavírus. < https://www.lexicovid19.com.br/>

Rio-Torto, G. M. (1998). Mecanismos da produção lexical no português europeu. ALFA, 42, 15-32.

Sánchez, A. et al. (Dir.) (1995). CUMBRE - Corpus Lingüistico del Español Contemporáneo - Fundamentos, Metodología y Aplicaciones. Madrid: SGEL.

Sękowska, E. (2012). Neologizmy slowotwórcze we wspólczesnej polszczyznie (wybrane tendencje). Eslavistica Complutense, 12, 97-103.

Teixeira, M. (2010). Léxico português e brasileiro - (In) Paralelismos. In M. C. Lima-Hernandes, \& K. Chulata (Orgs.), A língua portuguesa em foco: ensino-aprendizagem, pesquisa e tradução (pp. 21-34). Lecce: Pensa MultiMedia Editore.

Turazza, J. S. (1996). Léxico e criatividade. São Paulo: Pleide.

Vilela, M. (1994). Estudos de lexicologia do português. Coimbra: Livraria Almedina.

.(1995). Ensino da língua portuguesa: Léxico, dicionário, gramática. Coimbra: Livraria Almedina.

Villalva, A.; Silvestre, J. P. (2014). Introdução ao Estudo do Léxico. Petrópolis, RJ: Vozes.

Visão. <https:/visao.sapo.pt/atualidade/sociedade/2020-05-16-vamos-la-falar-em-covides-as-palavras-quea-pandemia-colocou-na-nossa-boca/>

Zdziebłowski, S. (2020). Prof. Bralczyk: mam nadzieję, że wiele słów związanych z epidemią nie zostanie na długo. Nauka w Polsce, 09/06/2020. <https://naukawpolsce.pap.pl/aktualnosci/news,82594,prof-bralczyk -mam-nadzieje-ze-wiele-slow-zwiazanych-z-epidemia-nie-zostanie>

\section{Páginas web}

https://www.dicio.com.br/.

https://dicionario.priberam.org/

https://www.infopedia.pt/

https://nowewyrazy.uw.edu.pl/

https://sjp.pwn.pl/

https://wsjp.pl/

http://www.letras.ufmg.br/padrao_cms/?web=gtlex\&lang=1\&page=2329\&menu=1547\&tipo=1

https://www1.folha.uol.com.br/ilustrada/2020/05/entenda-como-o-coronavirus-pode-mudar-ate-nossojeito-de-falar-portugues.shtml (consultado em 08-04-2021).

https://www.sebrae.com.br/sites/PortalSebrae/ufs/pb/artigos/capacite-se-em-tempos-de-coronavirus,c114bf6e29502710VgnVCM1000004c00210aRCRD (consultado em 08-04-2021).

https://www.ifb.edu.br/reitori/23911-algumas-palavras-sobre-lidar-com-as-noticias-em-tempos-de-coronavirus 
https://agenciabrasil.ebc.com.br/saude/noticia/2020-08/transporte-em-tempos-de-coronavirus-e-tema-docaminhos-da-reportagem (consultado em 08-04-2021).

https://www.publico.pt/2020/04/01/p3/fotogaleria/amor-tempos-coronavirus-400887 (consultado em 0804-2021).

https://www.diariodaregiao.com.br/cidades/2020/05/1193621-pandemia-do-coronavirus-traz-a-tona-novas-palavras-e-termos.html

https://www.accamargo.org.br/sobre-o-cancer/noticias/covid-19-um-glossario-com-22-termos-para-voceconhecer (consultado em 08-04-2021).

https://nadwyraz.com/blog/blog-ubierz-sie-w-slowa/koronamowa-czyli-neologizmy-powstale-w-2020-r -w-zwiazku-z-pandemia-slownik-slow-covidowych (consultado em 12-04-2021).

https://polszczyzna.pl/koronamowa-czyli-neologizmy-powstale-w-2020-r-w-zwiazku-z-pandemia-slownik -slow-covidowych/ (consultado em 28-04-2021).

https://www.jpn.up.pt/2020/04/07/covid-19-as-palavras-que-entraram-no-nosso-vocabulario/ (consultado em 24-03-2021).

https://visao.sapo.pt/atualidade/sociedade/2020-05-16-vamos-la-falar-em-covides-as-palavras-que-a-pandemia-colocou-na-nossa-boca/ (consultado em 08-04-2021)

https://www.diariodaregiao.com.br/cidades/2020/05/1193621-pandemia-do-coronavirus-traz-a-tona-novas-palavras-e-termos.html (consultado em 08-04-2021).

https://www.dicio.com.br/coronga/ (consultado em 08-04-2021).

https://vejario.abril.com.br/cidade/girias-pandemia/ (consultado em 08-04-2021).

https://www.dicio.com.br/coronavirus/ (consultado em 07-04-2021).

https://michaelis.uol.com.br/busca? $\mathrm{r}=0 \& \mathrm{f}=0$ \&t=0\&palavra=Coronav\%C3\%ADrus (consultado em 24-032021).

https://www.lexico.pt/coronavirus/ (consultado em 24-03-2021).

https://sjp.pwn.pl/mlodziezowe-slowo-roku/haslo/koronaferie;6949159.html (consultado em 28-03-2021).

https://www.travelplanet.pl/blog/koronaferie-7-pomyslow-na-to-co-robic-w-czasie-kwarantanny/ (consultado em 23-03-2021).

https://www.tygodnikpowszechny.pl/koronaferie-wkrotce-sie-skoncza-162826 (consultado em 23-032021).

https://www.pyskowice.pl/kwarantanna-to-nie-koronaferie-ostrzegamy-przed-korzystaniem-z-boisk-silowni-plenerowych-placow-zabaw.html (consultado em 23-03-2021). 